being similar to the abnormalities produced by isoniazid in the marrows of experimental animals and in human subjects receiving isoniazid therapy. The exact cause of the change is unknown, but it has been attributed to disturbance of pyridoxine metabolism. The incidence of the abnormality in the present series might have been higher had iron deficiency, which was common in the group as a whole, been corrected before the bone-marrow examinations were made.

\section{Summary}

Two groups of tuberculous patients, 50 treated and 18 untreated, were investigated for abnormalities of folate and iron metabolism. In $30 \%$ of the 68 patients the marrows showed obvious megaloblastic changes. Hypersegmented polymorphs were seen in about one-third of the peripheral blood films, and serum folate levels below the lower limit of a control series were found in $35 \%$ of the patients. Figlu tests were positive in $47 \%$, and red-cell folate levels were subnormal in $33 \%$ of the small unselected proportion of the patients tested. Folate deficiency was equally common among the treated and untreated patients, and its incidence bore no relation to the clinical extent of the disease or to the length or type of chemotherapy.

Excess stainable iron was present in the erythroblasts of 19 $(30 \%)$ of the 63 patients whose marrows were suitable for assessment. The iron granules were coarser than normal, were increased in number, and were often perinuclear in distribution. One patient showed obvious ring sideroblastic change. Increase in marrow iron was confined to patients receiving chemotherapy, and was particularly common in patients treated with isoniazid and P.A.S. for longer than six months, occurring in $16\left(57^{\prime \prime}{ }^{\prime}\right)$ of these 28 patients. Some of these patients also had raised serum iron levels and increased saturation of the iron-binding capacities.

We wish to thank Dr. E. Rhys-Jones and Dr. V. U. Lutwyche, chest physicians to the Harlow Group of Hospitals, for permission to study patients under their care. We are also grateful to Dr. Rhys-Jones for the clinical and $x$-ray classifications of the patients; to Dr. Barbara H. MacGibbon for helpful discussions ; and to Mr. J. Morgan, Miss B. Newcombe, Miss B. Peart, and Mrs. M. Potter for technical assistance.

\section{REFERENCES}

Anderson, B. B. (1964). F. clin. Path., 17, 14.

Bainton, D. F., and Finch, C. A. (1964). Amer. F. Med., 37, 62 Booth, C. C., McIntyre, I., and Mollin, D. L. (1964). Quart. F. Med., 33, 401 .

Bowman, W. D. (1961). Blood, 18, 662.

Caraway, W. T. (1963). Clin. Chem., 9, 188.

Chanarin, I. (1963). Brit. F. Haemat., 9, 141.

- and Bennett, M. C. (1962). Brit. med. 尹., 1, 27.

Dacie, J. V., and Lewis, S. M. (1963). Practical Haematology, 3rd ed. Churchill, London.

Doig, A., and Girdwood, R. H. (1960). Quart. F. Med., 29, 333.

Foster-Carter, A. F., Myers, M., Goddard, D. L. H., Young, F. H., and Benjamin, B. (1952). Brompton Hosp. Rep., 21, 1.

Hansen, H. A. (1964). On the Diagnosis of Folic Acid Deficiency. Almqvist and Wiksell, Stockholm.

Harriss, E. B., MacGibbon, B. H., and Mollin, D. L. (1965). Brit. F. Haemat., 11, 99 .

Hawksley, J. C., and Meulengracht, E. (1936). Lancet, 2, 124.

Herbert, V. (1959). The Megaloblastic Anaemias. Grune and Stratton, New York. (1962). Trans. Amer. Ass. Phycns, 75, 307.

Hoffbrand, A. V., Newcombe, B. F. A., and Mollin, D. L. (1966). J. clin. Path., 19, 17.

Kohn, R., Heilmeyer, L., and Clotten, R. (1962). Dtsch. med. Wschr., 87, 1765 .

McCurdy, P. R. (1963). Clin. Res. Proc., 11, 59.

MacGibbon, B. H., and Mollin, D. L. (1965). Brit. F. Haemat., 11, 59.

Mollin, D. L., and Hoffbrand, A. V. (1965). In Vitamin Ba and Folic Acid, Series Haemat. 3, p. 1. Munksgaard, Copenhagen. and Ross, G. I. M. (1952). F. clin. Path., 5, 129.

Oswald, N. C. (1963). Brit. med. भ., $2,1489$.

Perkins, J., Israëls, M. C. G., and Wilkinson, J. F. (1964). Quart. F. Med., 33, 499 .

Redleaf, P. D. (1962). Dis. Chest, 42, 222.

Rich, A. R. (1951). In The Pathogenesis of Tuberculosis, 2nd ed., p. 618. Blackwell, Oxford.

Richmond, J., and Davidson, S. (1958). Quart. F. Med., 27, 517.

Thompson, R. B., and Ungley, C. C. (1955). Blood, 10, 771 .

Undritz, E. (1952). Sandoz Atlas of Haematology, p. 57. Sandoz, Basle. Verwilghen, R. L, Lahaye, D. van Orshoven, A., and Reybrouck, G. (1963). 9th Congr europ. Soc. Haemat., Lisbon, Abstracts, 32. (1963). Gin Congr. elleps, L., Haend Cosemans, J. (1965), Brit. Haemat., 11, 92 .

Waters, A. H., and Mollin, D. L. (1961), 7. clin. Path., 14, 335.

\title{
Folic-acid Deficiency in Elderly Patients Admitted to Hospital
}

\author{
A. D. F. HURDLE,* M.R.C.P.ED., M.C.PATH. ; T. C. PICTON WILLIAMS, † M.D., M.R.C.P.
}

During routine haematological investigations at the South Western Hospital in 1964 many elderly people had low levels of folate in their serum. In order to establish the incidence of a low serum folate and to attempt to determine its cause we decided to investigate patients over 70 years old admitted to hospital.

A similar investigation into the folic acid status of men and women admitted to an old people's home in Bristol has recently been published (Read et al., 1965). We were able to explore the problem more extensively in a hospital population and to confirm that folic-acid deficiency is common in old age and that dietary deficiency is almost certainly the principal cause.

It was decided to use a faecal fat analysis and a folic-acidabsorption test to diagnose intestinal malabsorption. The D\footnotetext{
Lecturer in Haematology, St. Thomas's Hospital Medical School,
London.

† Consultant Physician, Geriatric Unit, South Western Hospital, London; Lecturer in Geriatrics, St. Thomas's Hospital Medical School, London.
}

xylose-excretion test was not used, as it is known to give low values in old people (Finlay and Wightman, 1958 ; Fowler and Cooke, 1960). Cases of folic-acid deficiency due to malignant disease, chronic infection, haemolytic anaemia, etc., or from taking anticonvulsant drugs were excluded by the clinical history and examination and routine blood tests. No patients had alcoholic cirrhosis. The hospital dietitian was asked to make an estimate of the folic acid consumed during the months preceding admission by means of a dietary history and published tables of food values (McCance and Widdowson, 1960).

\section{Material and Methods}

From April 1964 data were collected on 72 patients aged over 70. These people were an unselected group of consecutive admissions to the geriatric unit of the South-western Hospital. There were 46 females and 26 males, the clinical diagnoses on admission being arranged in groups in order of frequency 
(Table I). No patient suffered from hepatic cirrhosis. In this age group multiple pathology is the rule, and only the principal condition is mentioned. Of these 72 patients 63 had been visited at home by one of us (T.C.P.W.) on the day of admission to hospital, details of the medical and social circumstances being noted at the time. Five were admitted from local authority welfare homes and four had been referred by the family doctor to the outpatient department. The following tests were performed on admission:

Haemoglobin was estimated by a standard oxyhaemoglobin method (Dacie and Lewis, 1963).

White-cell counts were made with a $1: 20$ dilution of blood in $1 \%$ acetic acid in a bulb pipette. The counts were performed in a Neubauer chamber.

Serum folate was measured, using Lactobacillus casei, as described by Waters and Molin (1961). The normal range in our hands was $5-32 \mathrm{~m} \mu \mathrm{g} . / \mathrm{ml}$.

Serum vitamin $B_{12}$ was measured by means of L. leichmannii slightly modified from the method of Spray (1955). The normal range is $140-900 \mu \mu \mathrm{g} . / \mathrm{ml}$.

Formiminoglutamic Acid (Figlu).-A histidine load test was performed on 52 patients within 24 hours of admission. It took the form of an overnight screening test (Husain et al., 1963). The early morning urine, after $15 \mathrm{~g}$. of histidine given the night before, was subjected to electrophoresis (Kohn et al., 1961). Results were compared with a standard solution of $50 \mu \mathrm{g}$. of Figlu per $\mathrm{ml}$. of normal urine and recorded as positive, if the colour of the spot was denser than that of the standard, or negative.

Neutrophil Lobe Counts.-Blood films were stained by Leishman's method and 100 neutrophils counted. The number of cells with more than four lobes to the nucleus was noted. Chanarin et al. (1965) state that more than $3 \%$ of such cells is suggestive of megaloblastic change. Cell counts of this type are subject to observer variation because of differences of opinion about what constitutes a nuclear lobe (Herbert, 1964), and each laboratory should establish its own normal figures. In our hands the presence of more than $4 \%$ of cells with more than four lobes suggests megaloblastosis.

Blood urea was determined in all cases by use of a diacetylmonoxime method with a Technicon AutoAnalyzer (Skeggs, 1957).

With the exception of those who died within a few days of admission, patients whose serum folate was less than $5 \mathrm{~m} \mu \mathrm{g} . / \mathrm{ml}$. were the subjects of the following tests:

Bone-marrow aspirations were performed on the iliac crest of 27 of the 28 patients who had a low serum folate. Films were prepared with May-Grünwald-Giemsa stain for general morphology, and with Perls's stain to assess the stored iron.

Faecal Fat.-A 72-hour stool collection was made from 16 of the 28 patients with low serum folate. Total fatty acids were estimated by the method of van de Kamer et al. (1949). The upper limit of normal in adults is usually accepted as $6 \mathrm{~g} . / 24$ hours, but most individuals excrete less than 5 g. $/ 24$ hours. The 24 -hour faecal-fat excretion in the 16 patients with low serum folate was compared with that in nine patients of comparable age whose serum folate was normal.

Folic-acid absorption.-This was measured by the method of Chanarin et al. (1958). In this test folic acid in the serum is measured after an oral dose of pteroylglutamic acid, a Streptococcus faecalis assay being used. Normal subjects show $0-3 \mathrm{~m} \mu \mathrm{g} . / \mathrm{ml}$. before the dose and more than $40 \mathrm{~m} \mu \mathrm{g} . / \mathrm{ml}$. at one hour and two hours afterwards, according to the authors of the method. In our hands, for several months the assay gave consistently high readings until a different batch of growth medium was used. Fortunately for this investigation all our analyses in patients and control groups were made with the original batch of medium. Results were com-

Table I.-Principal Diagnoses of 72 Patients Aged Over 70 Years on Admission to Hospital Diagnosis

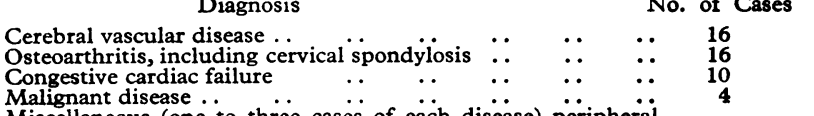

Miscellaneous (one to three cases of each disease) peripherai vascular disease, Parkinsonism, depression, bronchiectasis, bronchitis, rheumatoid arthritis, gout, diabetes, irondeficiency anaemia, epilepsy, cataract, hiatus hernia, erysipelas, malnutrition, tertiary syphilis .. pared in 14 patients over 70 years with low serum folate (1.8-4.8 $\mathrm{m} \mu \mathrm{g} . / \mathrm{ml}$. measured with $L$. casei), seven patients in the same age group whose serum folate was normal ( 5.6 to $24 \mathrm{~m} \mu \mathrm{g} . / \mathrm{ml}$.), two patients with idiopathic steatorrhoea whose serum folates were 1 and $3 \mathrm{~m} \mu \mathrm{g} . / \mathrm{ml}$. respectively, and eight normal young laboratory workers whose serum folates ranged from 8 to $19 \mathrm{~m} \mu \mathrm{g} / \mathrm{ml}$.

\section{Clinical and Social Data}

An attempt was made to assess the functional capacity of each patient in relation to his or her home environment, and to this end as many patients as possible were visited at home as soon as the general practitioner had applied for admission. A preliminary medical examination and a planned inquiry into the social and financial circumstances, the structural hazards and obstacles of the home, family relationships, and availability of local authority welfare services were carried out. After admission the initial medico-social assessment was augmented as necessary by further full clinical examination, by interviews with relatives, and by liaison with the local health departments through the hospital medical social workers. Degrees of physical disability were graded as: (a) fully active ; $(b)$ partially housebound-that is, out for essential purposes only ; $(c)$ housebound; and $(d)$ confined to one room and/or bed.

One aspect of mental frailty was considered-namely, impaired motivation-ranging from simple apathy or disinterest in preparing food to loss of initiative accompanying actual dementia. Cases of depression were also included.

This information was used to divide cases into groups according to their general mobility and ability to "forage" and prepare food. This was done without knowledge of the serum folate values. Factors influencing mobility were clinical, such as osteoarthritis, chronic heart failure, and senescence, or social, such as poor cooking facilities and poverty. The situations were never simple, many factors being concerned in each case. The picture was further complicated by the willingness of neighbours or relations to give help where needed. Some patients were provided with " meals on wheels" by the local authority social services but would not eat what they were given. Three groups of patients were compared.

Group 1 consisted of 38 patients whose disabilities were thought to be mild or moderate and whose mental capacities were normal.

Group 2 consisted of 13 patients severely affected by chronic disease to the extent that they had been confined to one room at home for at least two months before admission. Their mental state was judged to be normal.

Group 3 contained 18 patients, none of whom was confined to one room at home but who lacked motivation. All such persons had "withdrawn" into themselves to a greater or less extent, so that whatever their clinical or social circumstances their ability to look after themselves was impaired. Three patients with impaired mental function were not included, because their physical disability was severe enough to confine them to one room.

\section{Results}

Serum folate was low, less than $5 \mathrm{~m} \mu \mathrm{g} . / \mathrm{ml}$. in 28 patients. Fig. 1 shows the haemoglobin in these subjects. Only 12 were anaemic ; two of these had a megaloblastic marrow, five were iron-deficient, one had malignant disease, two were uraemic, and one mildly anaemic without obvious cause ( $\mathrm{Hb} 12.3 \mathrm{~g} . / 100$ ml.). One patient was probably megaloblastic in that his $\mathbf{H b}$ was $12.9 \mathrm{~g} . / 100 \mathrm{ml}$., his neutrophil lobe count was $5 \%$, and he was Figlu-positive. The bone-marrow, unfortunately, was not examined.

Serum vitamin $B_{12}$ varied between 120 and $850 \mu \mu \mathrm{g} . / \mathrm{ml}$., with a mean figure of $374 \mu \mu \mathrm{g} . / \mathrm{ml}$. One patient with Addisonian pernicious anaemia, whose serum vitamin $\mathbf{B}_{12}$ was $80 \mu \mu \mathrm{g} . / \mathrm{ml}$., was excluded. Four patients had values between 
120 and $140 \mu \mu \mathrm{g} . / \mathrm{ml}$., in all of whom the bone-marrow was normoblastic.

Neutrophil lobe counts (Fig. 2).-Twenty-eight patients had a serum folate less than $5 \mathrm{~m} \mu \mathrm{g} . / \mathrm{ml}$., of whom $11(39 \%)$ had more than $4 \%$ of hypersegmented neutrophils. Of the 44 patients with normal serum folate $7(16 \%)$ had more than $4 \%$. Hypersegmented neutrophils are found occasionally in chronic renal disease unassociated with vitamin $B_{12}$ or folic-acid deficiency (Herbert, 1964). However, the blood urea ranged from 18 to $42 \mathrm{mg}$. $/ 100 \mathrm{ml}$. in all patients showing hypersegmented neutrophils in this series. There was no obvious explanation for the presence of such cells in the patients whose serum folate was normal.

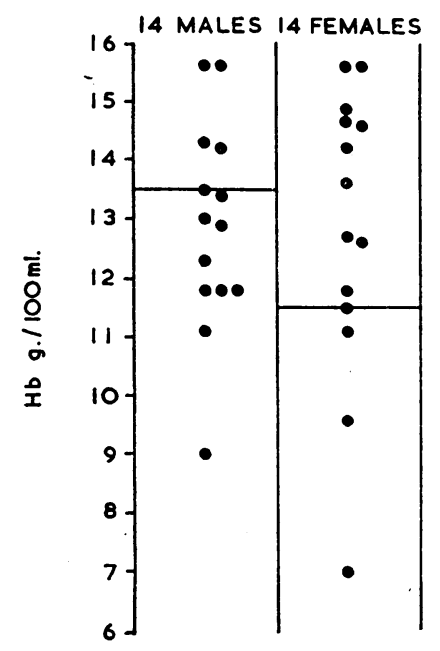

FIG. 1.-Haemoglobin in 28 patients whose serum folate was $<5 \mathrm{~m} \mu \mathrm{g}$. $/ \mathrm{ml}$. The lower limit of normal in males and females is

Figlu (Fig. 3).-Of the total 52 tests performed 16 were carried out in patients who had a low serum folate, $8(50 \%)$ of them giving a positive result. Thirty-five tests were carried out in patients whose serum folate was normal, 4 (11\%) being recorded as positive. Factors other than vitamin $B_{12}$ and folic acid are known to affect Figlu excretion, liver disease being one (Knowles et al., 1963). This was not excluded in 'any of our cases, there being no clinical indication to do so.
Bone-marrow.-Only two of the 27 marrows examined in the group of patients with low serum folate were megaloblastic. Four of the remaining 25 cases had a few giant metamyelocytes in the marrow, but the majority showed no abnormality of erythropoiesis or granulopoiesis. Perls's stain showed 21 cases to have normal marrow iron. Scanty iron granules were found in the marrow fragments of three cases, and in a further three cases no iron was demonstrable.

Dietary folic acid.-Fig. 4 shows no relation between the calculated folic-acid intake preceding admission (as determined from a dietary history and published tables) and the serum folate of 34 cases in the series. No further patients were studied in this way.

Tests for malabsorption were carried out on 16 of the 28 patients with low serum folate. Four patients were excluded because this finding may have been the result of malignant disease (two cases) or because of taking barbiturates (one case) or of chronic infection (one case). Seven other patients died before further investigations were performed.

Faecal-fat excretion.-There was no difference between the "low folate" and "control" groups. Sixteen patients whose serum folate was low excreted 0.9 to $6.4 \mathrm{~g} . / 24$ hours, with a mean of $3.5 \mathrm{~g}$. Nine patients, also over 70 years of age, with a normal serum folate, excreted 0.8 to $7.7 \mathrm{~g} . / 24$ hours, with a mean of $2.9 \mathrm{~g}$.

Folic-acid absorption.-Fig. 5 shows the range of results in the low folate and two control groups. It should be noted that the highest figures in each group coincide. Again there was no difference between the 14 cases with low serum folate and those in either the group of elderly patients with normal serum folate or the younger controls. Both control patients with idiopathic steatorrhoea had very low levels of serum folic acid after oral dose.

Social data (Table II).-A significant relationship was found between the number of cases with low serum folate in the three groups described and the severity of the disability $(P<0.01)$. Group 3 (lacking motivation) contains the greatest number of patients whose serum folate was reduced. Group 2 (severe physical handicap) also contains proportionately more than the less severely affected group 1. Attempts to correlate the serum folate with further subdivision of disability failed to show any significant relationship. It may seem surprising that any patients so severely incapacitated as those in groups 2 and 3 could have normal levels of folate in the serum. It should be

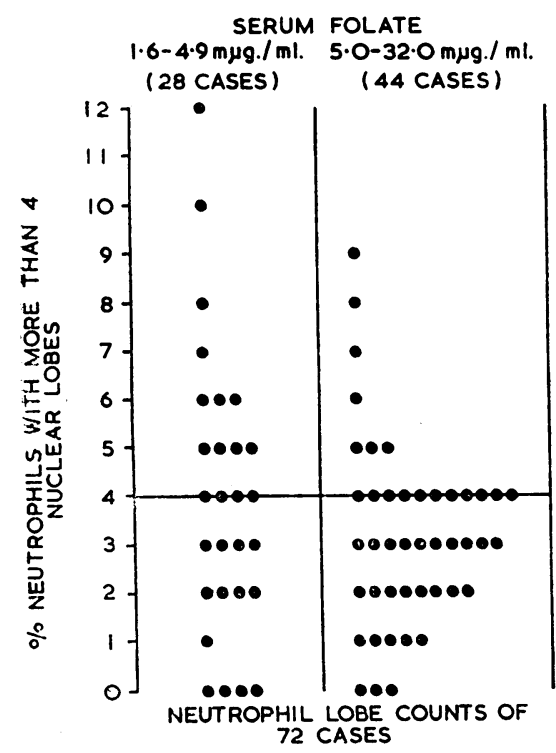

Fig. 2.-Neutrophil lobe counts of 72 patients related to serum folate. The normal range of neutrophils with more than four nuclear lobes is $0-4 \%$.

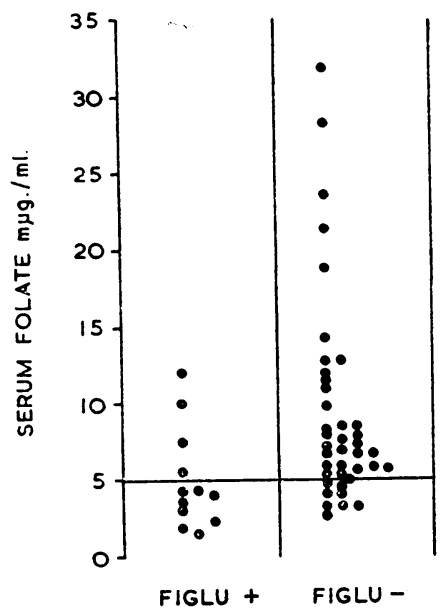

FIG. 3.-Figlu tests in 52 patients related to serum folate.

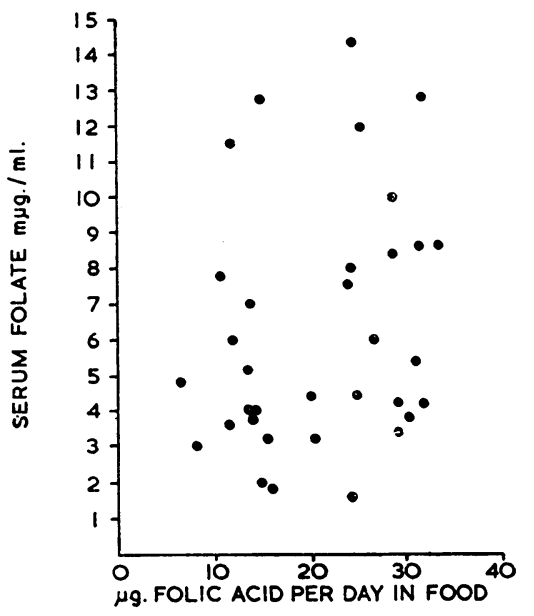

FIG. 4.-Folic acid eaten daily before admission, as calculated from published tables, plotted against serum folate ( $L$. 
remembered that many social factors are involved, including some which are not easily determined. Even a grossly senile person lacking in motivation may be well cared for by a devoted relative.

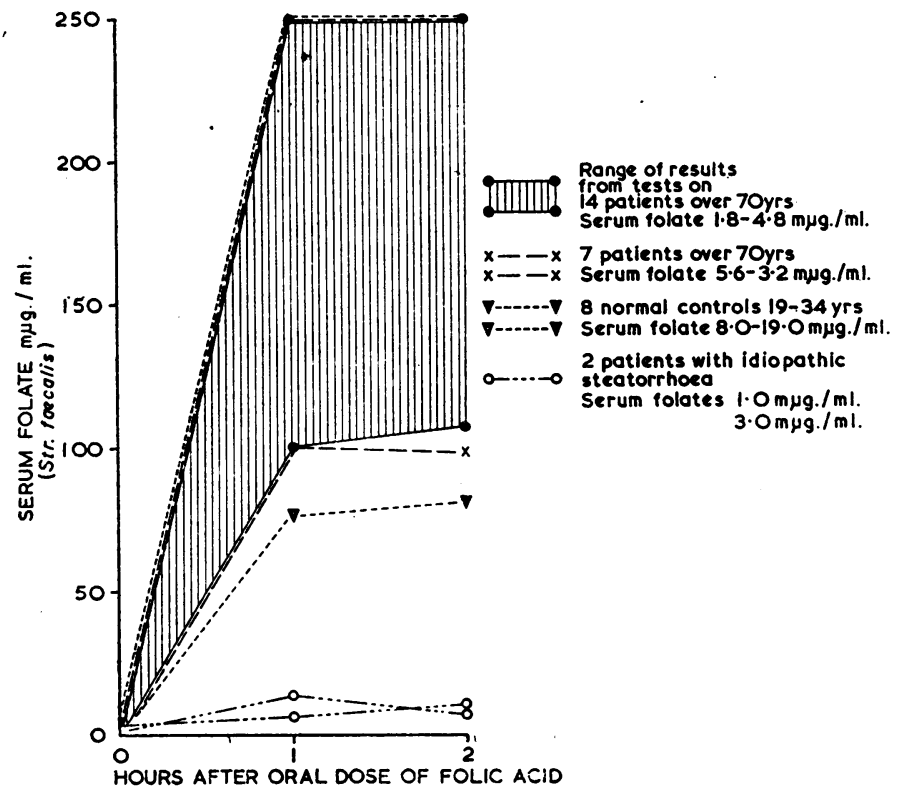

FIG. 5.-Folic-acid absorption tests on 14 patients with a low serum folate and 17 controls. Note that the highest figures in the test and the control group coincide.

\begin{tabular}{|c|c|c|}
\hline Group & $\begin{array}{c}\text { No. of Cases } \\
\text { having Serum } \\
\text { Folate }<5 \mathrm{~m} \mu \mathrm{g} . / \mathrm{ml} .\end{array}$ & $\begin{array}{l}\text { Total } \\
\text { No. of } \\
\text { Cases }\end{array}$ \\
\hline $\begin{array}{l}\text { 1. Mobility mildly to moderately im- } \\
\text { paired. Mental state normal . } \\
\text { 2. Mobility severely impaired. Mental } \\
\text { state normal } \\
\text { 3. Motivation impaired. Not severely } \\
\text { handicapped physically .. .. }\end{array}$ & $\begin{array}{r}8 \\
5 \\
12\end{array}$ & $\begin{array}{l}36 \\
13 \\
18\end{array}$ \\
\hline
\end{tabular}

For these results: $\mathrm{Chi}^{2}=15.80$ with 2 d.f. $\quad \mathrm{P}<0.01$.

\section{Discussion}

More than one-third of the 72 patients investigated had a low level of folate in their serum-that is, less than 5 $\mathrm{m} \mu \mathrm{g} . / \mathrm{ml}$. That this finding was due in many cases to a deficiency of folate in the body and not simply to physiological lowering in old age is indicated by the occurrence of positive Figlu (50\% of the cases tested) and hypersegmented neutrophils $(39 \%)$ in the group. That such changes may precede the onset of actual megaloblastic anaemia is well shown by Herbert (1962). Only two patients had a folic-acid-deficient megaloblastic anaemia. The faecal-fat analyses and folic-acid absorption tests used here serve to exclude severe malabsorption, and it seems unlikely on general grounds that a mild isolated absorption defect could be so widespread in the population.

The incidence of low serum folate in the three social groups described, increasing as it does with the severity of disability, is suggestive of a nutritional origin for the deficiency. It is worth noting that $67 \%$ of patients unable to look after themselves because of mental disorders were folate-deficient. It should be stressed that no other common factors likely to affect folic-acid metabolism could be found within the groups and that the patients were arranged within these groups before the serum folate results were known.

It is extremely difficult to obtain evidence of lack of dietary folic acid by taking a history. We found the attempt quite unrewarding. In the first instance many people had trouble remembering what they had eaten even the day before questioning. Despite the fact that an elderly person's diet is unlikely to change as much as that of someone younger, it is difficult to see how one could gain any useful impression of what was eaten three months before. A further source of error lies with the published tables of food values. The folic-acid content of foods is currently a controversial subject. The figures available were almost all obtained by $L$. casei assay without ascorbate in the growth medium. This substance has been shown to preserve the labile folate compounds which otherwise are not detected (Herbert, 1963). Even allowing for this it is uncertain how much of the $L$. casei-active material in food, not all of which is folate (Butterworth et al., 1963), is available for absorption. Finally, published tables take no account of the folic acid destroyed in cooking.

The evidence presented above strongly suggests nutritional folic-acid deficiency, but proof is dependent on measurement of dietary intake. This is manifestly impossible by calculation from the patient's history and published tables of food values, as shown here. It is clearly desirable to have more accurate data on folic acid consumed in the diet, and further studies on this are in progress.

The clinical importance of dietary-folic-acid deficiency in geriatric hospital admissions may seem small, as most subjects were not anaemic. However, it was the cause of megaloblastic anaemia in two patients, and may well have been concerned in the pathogenesis of anaemia in another. It is probably more important as an index of a degree of malnutrition which might lead to megaloblastosis if the body is challenged by di:eases which increase folic-acid metabolism.

\section{Summary}

Seventy-two patients over the age of 70 years were investigated for folic-acid deficiency on admission to a geriatric hospital in South London. Low levels of serum folate were found in 28, and evidence is presented that dietary deficiency of this vitamin is chiefly responsible.

We would like to thank Professor G. Wetherley-Mein for his helpful criticism, and the nursing staff of the South Western Hospital for their untiring cooperation in collecting specimens. Thanks are also due to the staff of the Department of Pathology, Lambeth Hospital ; to Miss Jane Tyas for the folate assays; and to Miss Avril Butler, who typed the script.

\section{REFERENCES}

Butterworth, C. E., jun., Santini, R., and Frommeyer, W. B. (1963) 7. clin. Invest., 42, 1929.

Chanarin, I., Anderson, B. B., and Mollin, D. L. (1958). Brit. $\mathcal{~ J . ~}$ Haemat., 4, 156.

- Rothman, D., and Berry, V. (1965). Brit. med. F., 1, 480

Dacie, J. V., and Lewis, S. M. (1963). Practical Haematology, 3rd ed. Churchill, London.

Finlay, J. M., and Wightman, K. J. R. (1958). Ann. intern. Med., 49, 1332.

Fowler, D., and Cooke, W. T. (1960). Gut, 1, 67.

Herbert, V. (1962). Trans. Ass. Amer. Phycns, 75, 307.

- (1963). Amer. F. clin. Nutr., 12, 17.

- (1964). Proc. roy. Soc. Med., 57, 377.

Husain, O. A. N., Rothman, D., and Ellis, L. (1963). f. Obstet. Gynaec. Brit. Cwlth, 70, 821 .

Knowles, J. P., Shaldon, S., and Fleming, A. (1963). Clin. Sci., 24, 39.

Kohn, J., Mollin, D. L., and Rosenbach, L. M. (1961). F. clin. Path., 14, 345 .

McCance, R. A., and Widdowson, E. M. (1960). Spec. Rep. Ser. med. Res. Coun. (Lond.), No. 297.

Read, A. E., Gough, K. R., Pardoe, J. L., and Nicholas, A. (1965). Brit. med. F., 2, 843 .

Skeggs, L. T. (1957). Amer. f. clin. Path., 28, 311.

Spray, G. H. (1955). Clin. Sci., 14, 661.

van de Kamer, J. H., ten Bokkel Huinink, H., and Weyers, H. A. (1949). 7. biol. Chem., 177, 347.

Waters, A. H., and Mollin, D. L. (1961). f. clin. Path., 14, 335. 